\title{
Laboratoř neuropsychologie Neurologické kliniky 1. LF UK
}

\author{
Ondřej Bezdiček a Tomášs Nikolai
}

Neuropsychologie v Luriově vymezení je věda, která má za předmět studium činnosti mozku v komplexních formách duševní aktivity. Klinická neuropsychologie studuje tyto vzorce narušené aktivity u osob s neurologickým či psychiatrickým onemocněním. Jedná se o obor, který vyžaduje speciální dovednosti a znalosti, které nezahrnuje běžné kurikulum vzdělávacího oboru klinická psychologie. Vyžaduje znalost diagnostických postupů a neuropsychologických testů, hlubší znalost činnosti mozku a metod, které tuto činnost či strukturu popisují (například zobrazovací metody apod.). Propojuje v sobě informace několika oborů, zejména behaviorální neurologie, klinické psychologie, statistických postupů, neurofyziologie, základů neuroradiologie, neurorehabilitace a dalších. Specifickou činností je na jedné straně komplexní neuropsychologická diagnostika, na druhé straně komplexní kognitivní rehabilitace. Klinická neuropsychologie je neoddělitelně spjata s klinickou praxí. Neuropsychologická laboratoř Jiř́ho Diamanta navazuje na dlouholetou tradici klinického výzkumu v neuropsychologii na 1. lékařské fakultě Univerzity Karlovy (1. LF UK), který započal doc. MUDr. et PhDr. Jiř́i Diamant v roce 1953. Jeho emigrací v roce 1968 byla neuropsychologická činnost násilně přerušena. Od roku 2008 se na Neurologické klinice 1. LF UK a Všeobecné fakultní nemocnice v Praze postupně rozvíjely aktivity pod vedením prof. MUDr. Evžena Růžičky, DrSc. navazující na předchozí tradici klinické neuropsychologie na 1. LF UK.

Laboratoř neuropsychologie (LN) - Neuropsychologická laboratoř Jiř́ího Diamanta - je společnou základnou pro výzkum a výuku klinické a experimentální neuropsychologie v úzké návaznosti na klinický neurovědní výzkum a postgraduální studium neurověd a lékařské psychologie a psychopatologie na Neurologické klinice (NK). LN je řízena vedoucím z řad vědeckopedagogických pracovníků NK ve spolupráci s ostatními výzkumnými jednotkami (Centra extrapyramidových onemocnění, Centra pro demyelinizační onemocnění, Centra pro poruchy spánku a bdění, laboratoří klinické neurofyziologie a rehabilitačním oddělením NK). LN zajišt’uje zdravotnickou činnost ve své oblasti a podílí se na výuce a výzkumu dle požadavků přednosty. LN je základnou pro spolupráci s externími pracovišti, zejména v oblastech klinické a lékařské psychologie, psychologie ve zdravotnictví, zobrazovacích metod, neurochirurgie a psychofarmakologie. Výzkumný program neuropsychologické laboratoře se věnuje především neuropsychologické problematice u neurodegenerativních onemocnění a vývoji neuropsychologických metod pro diagnostiku poruch psychických funkcí.

\section{Základní činnosti laboratoře}

1) Zajišt'ování léčebné péče o pacienty Neurologické kliniky 1. LF UK a VFN v Praze.

2) Rozvíjení výzkumu psychofyziologických korelátů mozkové činnosti v součinnosti s neurovědním výzkumem na klinické a aplikované úrovni.

3) Integrace neuropsychologických metod do zobrazovacích, stimulačních, elektrofyziologických, farmakologických, rehabilitačních př́stupů pro zvyšování kvality péče o pacienty. 
4) Rozvíjení statistické analýzy testových metod v neuropsychologii a zavedení neuropsychologie založené na důkazech do vyšetření.

5) Vývoj a klinické ověřování výsledků cílených rehabilitačních metod zaměřených na zlepšení postižených kognitivních funkcí pacientů v rámci rehabilitačních programů.

6) Výuka a školení v oboru neuropsychologie.

\section{Klinická činnost}

\section{Neuropsychologická ambulance}

Neuropsychologická ambulance poskytuje odbornou klinicko-psychologickou a neuropsychologickou činnost pro pacienty, kteří jsou hospitalizovaní nebo v ambulantní péči Neurologické kliniky 1. LF UK a VFN v Praze.

Neuropsychologická ambulance poskytuje zejména následující odbornou psychologickou činnost:

1) Neuropsychologická a klinicko-psychologická diagnostika

2) Krizová intervence pro hospitalizované pacienty

3) Kognitivní rehabilitace a podpůrná psychoterapie

\section{Zakladatelé neuropsychologické laboratoře}

doc. Mgr. Ondřej Bezdíček, Ph.D.; doc. Mgr. Tomáš Nikolai, Ph.D.

\section{Garant neuropsychologické laboratoře}

prof. MUDr. Evžen Růžička, DrSc.

\section{Členové laboratoře}

doc. Mgr. Tomáš Nikolai, Ph.D.; doc. Mgr. Ondřej Bezdíček, Ph.D.; Mgr. Eva Straková, Ph.D.; PhDr. Olga Klempírová, Ph.D.; Mgr. Gabriela Věchetová, Ph.D.; Mgr. Lucie Friedová; Mgr. Zuzana Frydrychová

\section{Postgraduální studenti}

Mgr. Jiří Motýl; Mgr. Kateřina Bukačová; Mgr. Filip Havlík; Mgr. Josef Mana; Mgr. Vladimíra Plzáková; Mgr. Monika Dokoupilová; Mgr. Pavla Lhotová; Mgr. Klára Benešová

\section{Spolupráce}

Laboratoř neuropsychologie úzce spolupracuje s dalšími léčebnými složkami Neurologické kliniky, zejména s Centrem extrapyramidových onemocnění, Kognitivním centrem, MS centrem aj.

Výzkumná část laboratoře spolupracuje s celou řadou akademických pracovišt' v České republice i zahraničí, např́íklad Psychiatrická klinika 1. LF UK a VFN v Praze, Klinika dětské neurologie 2. LF UK a FN Motol, Oddělení klinické psychologie FN Motol, Národní ústav duševního zdraví v Klecanech, Institut neuropsychiatrické péče, Neuropsychiatrické fórum, 
Českomoravská psychologická společnost; Academisch Medisch Centrum, Amsterdam, Holandsko aj.

V r. 2020 laboratoř neuropsychologie, 1. LF UK podepsala smlouvu o spolupráci s Psychologickým ústavem AV ČR s cílem integrovat základní a klinický psychologický i neurovědní výzkum.

\section{Publikace}

https://www.researchgate.net/profile/Tomas-Nikolai

https://www.researchgate.net/profile/Ondrej-Bezdicek

\section{Odkazy}

https://neurologie.lf1.cuni.cz/1LFNK-207.html

https://www.vfn.cz/pacienti/kliniky-ustavy/neurologicka-klinika/odborne-ambulance/

Kontakt: ondrej.bezdicek@lf1.cuni.cz

Bezdíček, O. (2021). Laboratoř neuropsychologie Neurologické kliniky 1. LF UK. E-psychologie, 15(4), 95-97. https://doi.org/10.29364/epsy.427 